\title{
Communication
}

\section{Control of Seed-Borne Fungi by Selected Essential Oils}

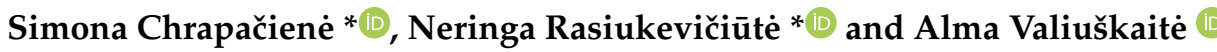

\begin{abstract}
Laboratory of Plant Protection, Institute of Horticulture, Lithuanian Research Centre for Agriculture and Forestry, Kaunas District, LT-54333 Babtai, Lithuania; alma.valiuskaite@lammc.lt

* Correspondence: simona.chrapaciene@lammc.lt (S.C.); neringa.rasiukeviciute@lammc.lt (N.R.)
\end{abstract}

Citation: Chrapačienè, S.; Rasiukevičiūtè, N.; Valiuškaitè, A Control of Seed-Borne Fungi by Selected Essential Oils. Horticulturae 2022, 8, 220. https://doi.org/ $10.3390 /$ horticulturae 8030220 Academic Editors: Hillary Righini, Roberta Roberti and Stefania Galletti

Received: 31 December 2021 Accepted: 28 February 2022 Published: 2 March 2022

Publisher's Note: MDPI stays neutral with regard to jurisdictional claims in published maps and institutional affiliations.

Copyright: (c) 2022 by the authors. Licensee MDPI, Basel, Switzerland. This article is an open access article distributed under the terms and conditions of the Creative Commons Attribution (CC BY) license (https:// creativecommons.org/licenses/by/ $4.0 /)$.

\begin{abstract}
Seed-borne pathogens reduce the quality and cause infections at various growth stages of horticultural crops. Some of the best-known are fungi of genus Alternaria, that cause destructive vegetable and other crop diseases, resulting in significant yield losses. Over several years, much attention has been paid to environmentally-friendly solutions for horticultural disease management regarding the environmental damage caused by chemicals. For example, plant extracts and essential oils could be alternative sources for biopesticides and help to control vegetable seed-borne pathogens. This study aimed to evaluate essential oils' influence on the growth of seed-borne fungi Alternaria spp. The microbiological contamination of vegetable seeds (carrot, tomato, onion) was determined by the agar-plate method. The essential oils' impact on the growth of fungi was evaluated by mixing them with PDA medium at different amounts. The hydrodistillation was used for extraction of thyme and hyssop essential oils, and common juniper essential oil was purchased. The investigation revealed that the highest contamination of carrot and tomato seeds was by Alternaria spp. fungi. Furthermore, the highest antifungal effect on Alternaria spp. growth was achieved using $200-1000 \mu \mathrm{L} \mathrm{L}^{-1}$ of thyme essential oil. Meanwhile, the antifungal effect of other investigated essential oils differed from low to moderate. Overall, essential oils expressed a high potential for fungal pathogens biocontrol and application in biopesticides formulations.
\end{abstract}

Keywords: Thymus vulgaris; Juniperus communis; Hyssopus officinalis; Alternaria spp.; biocontrol

\section{Introduction}

Vegetables are a crucial part of food production and are consumed worldwide. However, fungal diseases often lead to significant economic yield losses [1]. For example, horticultural production yield spoilage caused by fungal Alternaria species ranges from $20 \%$ to $80 \%$ [1,2]. This fungus can induce seedling death, petiole base blackening, leaf death or blight, leaf lesions, stem canker, black rot, and other symptoms depending on the host plant $[3,4]$. Alternaria spp. can also be considered a seed-borne pathogen, responsible for destructive diseases of various vegetables such as carrot, tomato, onion, etc. [1]. For example, Alternaria radicina Meier, Drechsler, and Eddy is known primarily as a carrot pathogen, responsible for root and crown disease and causing foliar blight under certain conditions. Alternaria dauci (Kühn) Groves and Skolko mainly cause carrot Alternaria leaf blight. However, $A$. dauci has also been documented to cause disease on parsnip, spinach, celery, and parsley [5]. Alternaria solani (Ellis and Martin) Sorauer causes early blight on foliage, collar rot on basal stems of seedlings, stem lesions on adult plants, and fruit rot of tomatoes [6]. Sources indicate that Alternaria arborescens Keissler also causes stem canker of tomato [7]. The purple blotch of onion is a disease caused by Alternaria porri (Ellis) Cif. [8]. Alternaria alternata (Fr.) Keissl. causes a black spot in many fruits and vegetables around the world. Some studies reported seed contamination with various Alternaria species, including saprotrophic A. alternata, Alternaria tenuissima Samuel Paul Wiltshire, Alternaria longipes (Ellis and Everh.) E.W. Mason [9-11]. In addition, due to its presence on the seeds' surface, Alternaria spp. can adversely affect seed germination [1,3,12]. Therefore, high-quality, fungifree seeds are prioritised because vegetable consumption increases yearly [3]. Seed-borne 
diseases can be controlled by selecting resistant varieties, production technology, seed treatments and dressings, and soil disinfection [13]. Over the last several decades, seed and soil or foliar treatments with synthetic chemicals have been shown to prevent plant disease epidemics caused by seed-borne fungi [14-19].

Nevertheless, following regulation No. 1452/2003 developed by the European Commission, organic horticulture is limited to using only organic seeds [20]. Therefore, fungicides in organic production are not used for seeds to prevent the influence of micromycetes. Additionally, their non-target impact on pathogen resistance gain risks to human health and other organisms. Chemical nature and horticultural products pollution by pesticide residues has encouraged the investigation for alternative solutions to control and make horticulture more sustainable [21,22].

Essential oils, due to their broad applicability in various industries, like pharmacy or food industries, have received much attention [23,24]. Furthermore, more comprehensive studies of essential oils revealed their potential in environmental-friendly horticultural disease management as they have antiseptic, antiviral, antibacterial, and antifungal properties $[25,26]$. Additionally, essential oils, as secondary metabolites, exhibit high plant defence effects, are non-toxic, biodegradable, and limit pathogenic organisms [24,27]. Due to these features, they can be applied as biopesticides for alternative plant protection. For example, Karaca et al. [28] reported good inhibition of investigated fungal species growth under oregano, mint, and clove essential oils application. Muthukumar et al. [29] also stated significant results of geranium and palmarosa essential oils efficacy against rice micromycetes of genera Cochliobolus and Fusarium. According to other studies, thyme essential oil has a potent antifungal effect on the development of fungal plant pathogens [19,24,25,28,30-33].

The literature review showed that there is a lack of studies regarding environmentally friendly ways to prevent fungal infections of vegetable seeds. Hence, the aim of this study was to determine the predominant seed-born fungi in carrot, tomato, and onion seeds, then to evaluate the antifungal activity of essential oils of thyme, hyssop, and common juniper on the growth of Alternaria spp.

\section{Materials and Methods}

\subsection{Seed Samples}

For the research, three seed samples of carrot, onion, and tomato were obtained from the Department of Vegetable Breeding and Technology, Institute of Horticulture (IH), Lithuanian Research Centre for Agriculture and Forestry (LAMMC) (Table 1).

Table 1. Vegetable seeds used in the experiments.

\begin{tabular}{ccc}
\hline Common Name & Botanical Name & Cultivar \\
\hline Carrot & Daucus carota sativus L. & Svalia \\
Tomato & Solanum lycopersicum L. & Rutuliai \\
Onion & Allium cepa L. & Babtu didieji \\
\hline
\end{tabular}

Vegetable seeds were surface-sterilised by rinsing them in $70 \%$ ethanol for 3 min and then washing them three times with sterile distilled water for $5 \mathrm{~min}$ in total [34]. After this, seeds were left to dry for 5-10 min in laminar flow. The internal seeds infestation with fungi was determined when external microorganisms were removed during surface sterilisation.

\subsection{Determination of Predominant Fungi}

The microbiological contamination of seeds samples was evaluated using the agarplate method [35]. The potato dextrose agar (PDA) medium (Sigma-Aldrich, St. Louis, $\mathrm{MO}$, USA) composed of $15 \mathrm{~g} \mathrm{~L}^{-1}$ agar, $20 \mathrm{~g} \mathrm{~L}^{-1}$ dextrose, and $4 \mathrm{~g} \mathrm{~L}^{-1}$ potato extract was autoclaved and distributed to the Petri dishes [36]. Prepared surface-sterilised samples were arranged in a square shape (five rows and five columns) on each Petri dish (Figure 1) and kept at $22 \pm 2{ }^{\circ} \mathrm{C}$ temperature in the dark $[37,38]$. 


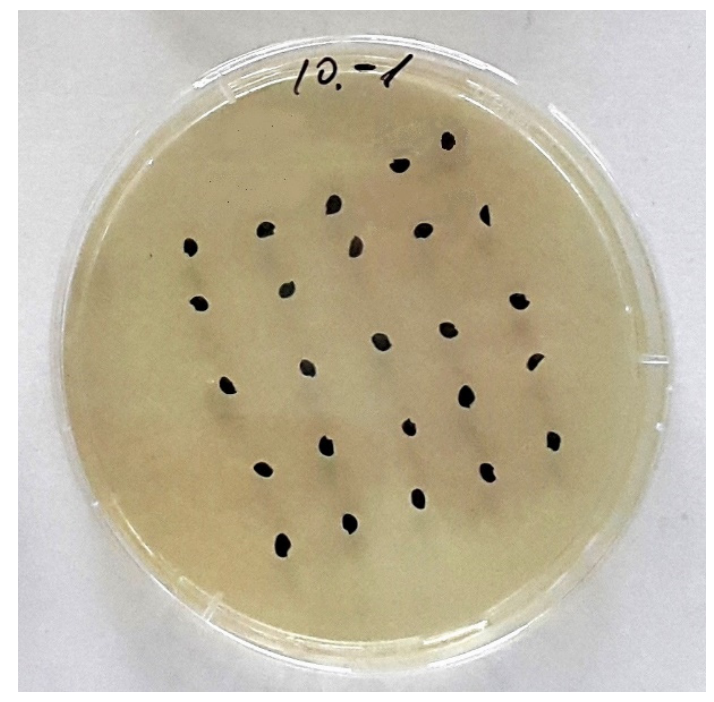

Figure 1. Arrangement of 25 seeds.

The experiment was repeated twice (four replications of each treatment). While inspecting the internal infestation of seeds, the settlements of fungi were counted to get the percentage of dominating fungi in the treatment after 2, 5, and 7 days of incubation (DOI). Visual and microscopical fungi identification was made based on morphological and cultural characteristics typical to the colonies [17,39]. Their detection frequency was determined using the detection rate of micromycetes: less than 30\%-random species, more than 30\%-typical species, more than 50\%—dominant species [40].

\subsection{Essential Oils Efficacy Assay}

Three essential oils of thyme (Thymus vulgaris L.), hyssop (Hyssopus officinalis L.), and common juniper (Juniperus communis L.) were used in the experiment. The essential oils of thyme and hyssop were separately hydro-distilled for $2 \mathrm{~h}$ using Clevenger type of apparatus [41] from naturally dried herb material, harvested from the experimental fields of IH, LAMMC. The essential oil of the common juniper was purchased (Naujoji Barmune, Vilnius, Lithuania). The major compounds of thyme essential oil: thymol (41.35\%), p-cymene $(16.95 \%)$, and $\gamma$-terpinene $(10.81 \%)$, were identified earlier by Morkeliūnè et al. [32]. The hyssop essential oil was characterised by cis-pinocamphone $(40.16 \%), \beta$-phellandrene $(12.51 \%)$, and $\beta$-pinene $(8.07 \%)$ and the process of chemical analysis was described previously by Šernaitè et al. [42]. The essential oil of the common juniper was mainly characterised by $\alpha$-pinene (21.0-67.4\%) and myrcene (7.8-18.7\%) chemotypes [43].

Then, different amounts of each essential oil were added to one litre PDA medium after cooling to $45^{\circ} \mathrm{C}$, to get $200,400,600,800$, and $1000 \mu \mathrm{L} \mathrm{L}^{-1}$ concentrations, then mixed and poured into new Petri plates [44]. A control treatment was without essential oil in PDA, prepared as previously described. Treatments with thyme essential oil were coded T1, hyssop-T2, and common juniper-T3. Surface-sterilised samples of each seeds cultivars were placed in the same order as before (Figure 1) on PDA with different essential oil concentrations and incubated at $22 \pm 2{ }^{\circ} \mathrm{C}$ in the dark for 7 days. There were four replicates for each vegetable seed cultivar, and the experiment was repeated twice.

The percentage of Alternaria spp. was calculated based on the number of grown fungal colonies in each plate after 2, 5, and 7 DOI. Fungi were identified according to cultural and morphological characteristics typical to the colonies [17,39]. Essential oils effect on Alternaria species was evaluated according to the disease incidence using the formula below (1) [12]: 
Lower disease incidence showed effective essential oil mean activity for seed-borne fungi control.

\subsection{Statistics}

The experimental data were analysed using the analysis of variance (ANOVA) from the software SAS Enterprise Guide 7.1 (SAS Institute Inc., Cary, NC, USA). Duncan's multiple range test $(p<0.05)$ was used to determine differences among the treatments.

\section{Results}

The fungal contamination of vegetable seeds at the 7 DOI is summarised in Table 2. Carrot seeds were infected by 100\%, and the predominant fungi were Alternaria spp. Fungi of genera Penicillium and Fusarium occurrence reached up to $4 \%$ and were considered random. However, the internal infection of tomato and onion seeds did not exceed $20 \%$. The Alternaria spp. also dominated on tomato seeds. Fungi of the genera Mucor and Penicillium were typical for onion seeds and Aspergillus and Mucor for tomato seeds.

Table 2. Seeds contamination with fungi after seven days of incubation.

\begin{tabular}{cccccccc}
\hline \multirow{2}{*}{ Seeds } & Total Seeds & \multicolumn{5}{c}{ Fungal Contamination, \% } \\
\cline { 3 - 7 } & Infected, \% & $\begin{array}{c}\text { Alternaria } \\
\text { spp. }\end{array}$ & $\begin{array}{c}\text { Fusarium } \\
\text { spp. }\end{array}$ & $\begin{array}{c}\text { Aspergillus } \\
\text { spp. }\end{array}$ & Mucor spp. & $\begin{array}{c}\text { Penicillium } \\
\text { spp. }\end{array}$ & $\begin{array}{c}\text { Mycelia } \\
\text { sterilia }\end{array}$ \\
\hline Carrot & 100 & 93.4 & 3.77 & 0 & 0 & 2.83 & 0 \\
Tomato & 20 & 50 & 0 & 15 & 25 & 0 & 10 \\
Onion & 15 & 20 & 0 & 0 & 40 & 40 & 0 \\
\hline
\end{tabular}

As Alternaria species prevailed as the dominant fungi in vegetable seeds, it was decided to test the influence of three essential oils (T1, T2, and T3) on the growth of seed-borne fungi Alternaria spp. in vitro.

The incidence of Alternaria spp. on carrot seeds under the influence of T1, T2, and T3 treatments is presented in Figure 2.

The treatments applied to carrot seeds showed an intermittent effect. In the case of treatments with T1, all concentrations significantly suppressed $(p<0.05)$ the growth of seed-borne fungi. Furthermore, no colonies were detected at 2 DOI regardless of the amount of essential oil. Meanwhile, the emergence of Alternaria species reached 33\% at 2 DOI, $36 \%$ at 5 DOI, and $64 \%$ at 7 DOI in the control treatment.

During the first assessment, seeds infection with Alternaria fungi was $1 \%$ at 400 and $1000 \mu \mathrm{L} \mathrm{L}^{-1}$ of T2 treatment. Later, the abundance of these fungi was higher: $63 \%(200 \mu \mathrm{L}$ $\left.\mathrm{L}^{-1}\right), 68 \%\left(400 \mu \mathrm{L} \mathrm{L}^{-1}\right), 74 \%\left(600 \mu \mathrm{L} \mathrm{L}^{-1}\right), 48 \%\left(800 \mu \mathrm{L} \mathrm{L}^{-1}\right)$, and $64 \%\left(1000 \mu \mathrm{L} \mathrm{L}^{-1}\right)$ at 5 DOI. Likewise, $400 \mu \mathrm{L} \mathrm{L}^{-1}$ of T2 cause significant decreation of Alternaria incidence at 7 DOI. However, the remaining T2 concentrations of $200,600,800$, and $1000 \mu \mathrm{L} \mathrm{L}^{-1}$ did not affect fungal growth-Alternaria spp. incidence increased compared with the control at 5 and 7 DOI. Thus, the opposite effect of T2 was observed than expected.

The T3 treatment performed weaker on Alternaria spp. on the second incubation day. Nevertheless, the $600 \mu \mathrm{L} \mathrm{L}^{-1}$ had the best antifungal activity. The $200 \mu \mathrm{L} \mathrm{L}^{-1}$ and $600-1000 \mu \mathrm{L} \mathrm{L}^{-1}$ of T3 slightly controlled the prevalence of the fungi compared to controls at 5 DOI and did not differ significantly at 7 DOI. Still, the best fungal incidence suppression was exhibited by $400 \mu \mathrm{L} \mathrm{L}^{-1}$ of this treatment at the fifth and seventh DOI. 


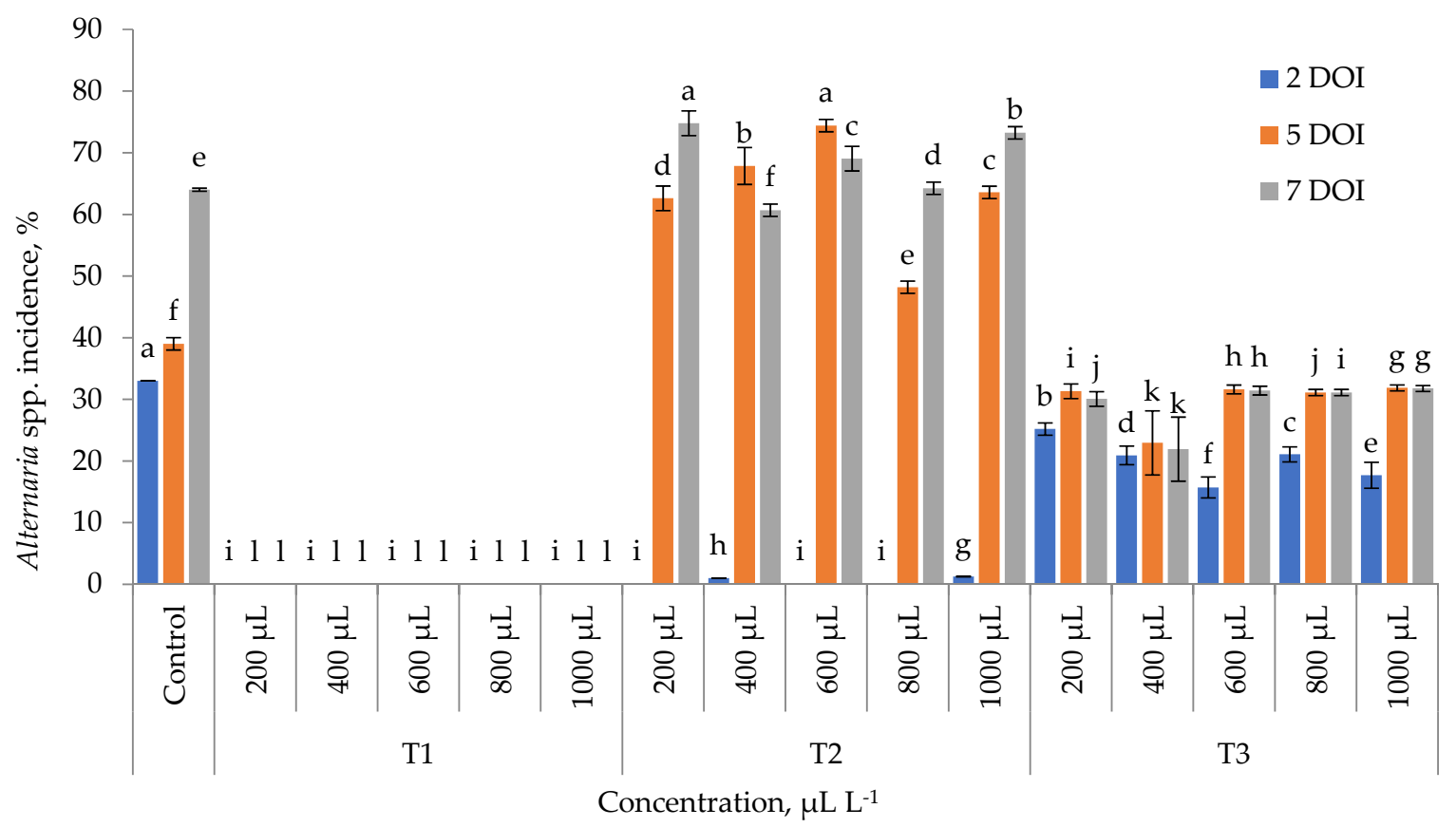

Figure 2. The incidence of Alternaria spp. on carrot seeds under the influence of thyme (T1), hyssop (T2), and common juniper (T3) essential oils treatments after 2, 5, and 7 days of incubation (DOI); according to Duncan's multiple range test $(p<0.05)$, the same letters demonstrate no significant differences between treatments at 2, 5, and 7 DOI.

The incidence of Alternaria spp. on tomato seeds under T1, T2, and T3 treatments is presented in Figure 3. Evaluating the effect of T1 concentrations from 200 to $1000 \mu \mathrm{L} \mathrm{L}^{-1}$, no colonies of Alternaria spp. were observed at 2 and 5 DOI. However, $6 \%$ incidence was reached at 7 DOI under $200 \mu \mathrm{L} \mathrm{L}^{-1}$.

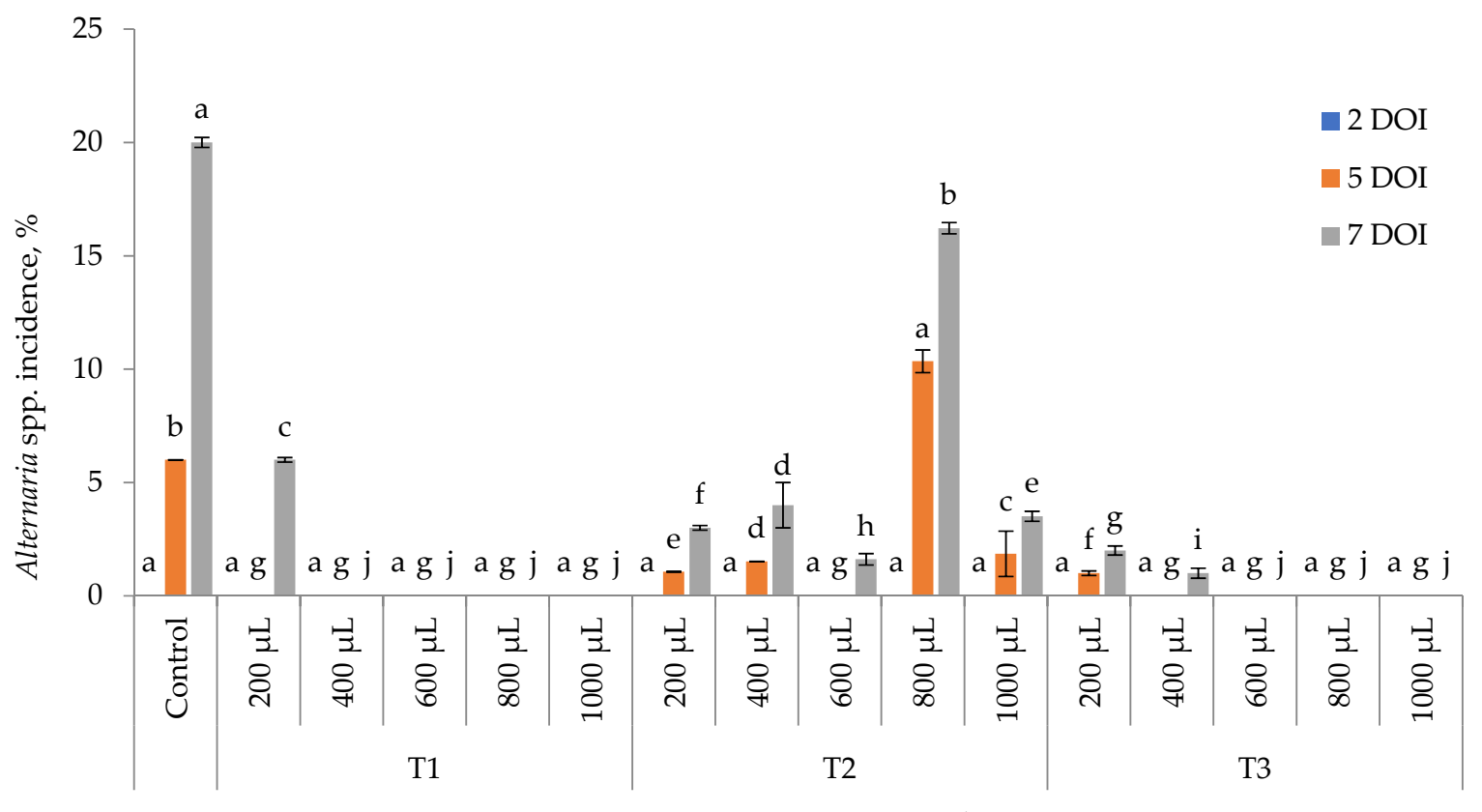

Concentration, $\mu \mathrm{L} \mathrm{L}^{-1}$

Figure 3. The incidence of Alternaria spp. on tomato seeds under the influence of thyme (T1), hyssop (T2), and common juniper (T3) essential oils treatments after 2, 5, and 7 days of incubation (DOI); according to Duncan's multiple range test $(p<0.05)$, the same letters demonstrate no significant differences between treatments at 2, 5, and 7 DOI. 
Meanwhile, T2 performed a weaker impact on fungi occurrence, although no fungal colonies were noticed at 2 DOI. The development of micromycetes was observed: $1 \%$ under $200 \mu \mathrm{L} \mathrm{L}^{-1}, 2 \%-400 \mu \mathrm{L} \mathrm{L}^{-1}, 10 \%-800 \mu \mathrm{L} \mathrm{L}^{-1}$, and $2 \%-1000 \mu \mathrm{L} \mathrm{L}^{-1}$ at 5 DOI. During the third estimation, the number of Alternaria spp. increased $2-6 \%$ from the previous evaluation. However, none of the T2 values exceeded those of the control incidence; the prevalence value of Alternaria spp. came up with $6 \%$ at 5 DOI and $20 \%$ at 7 DOI.

Estimation of tomato seeds incidence with Alternaria species at different concentrations of T3 revealed that fungi infected $1 \%$ of seeds under the lowest concentration used at 5 DOI. Later, the incidence increased to $2 \%$ under $200 \mu \mathrm{L} \mathrm{L}^{-1}$ and $1 \%$ under $400 \mu \mathrm{L} \mathrm{L}^{-1}$ of T3 at 7 DOI. The T3 treatment concentrations from $600 \mu \mathrm{L} \mathrm{L}^{-1}$ had significant antifungal activity at 2,5 , and 7 DOI.

The influence of T1, T2, and T3 treatments on the onion seeds infestation with Alternaria spp. is presented in Figure 4. At 5 DOI, the frequency in control was $18 \%$, and at 7 DOI, $20 \%$. The assay with T1 (200-1000 $\left.\mu \mathrm{L} \mathrm{L}^{-1}\right)$ revealed total development inhibition of the genus Alternaria fungi at all assessment days.

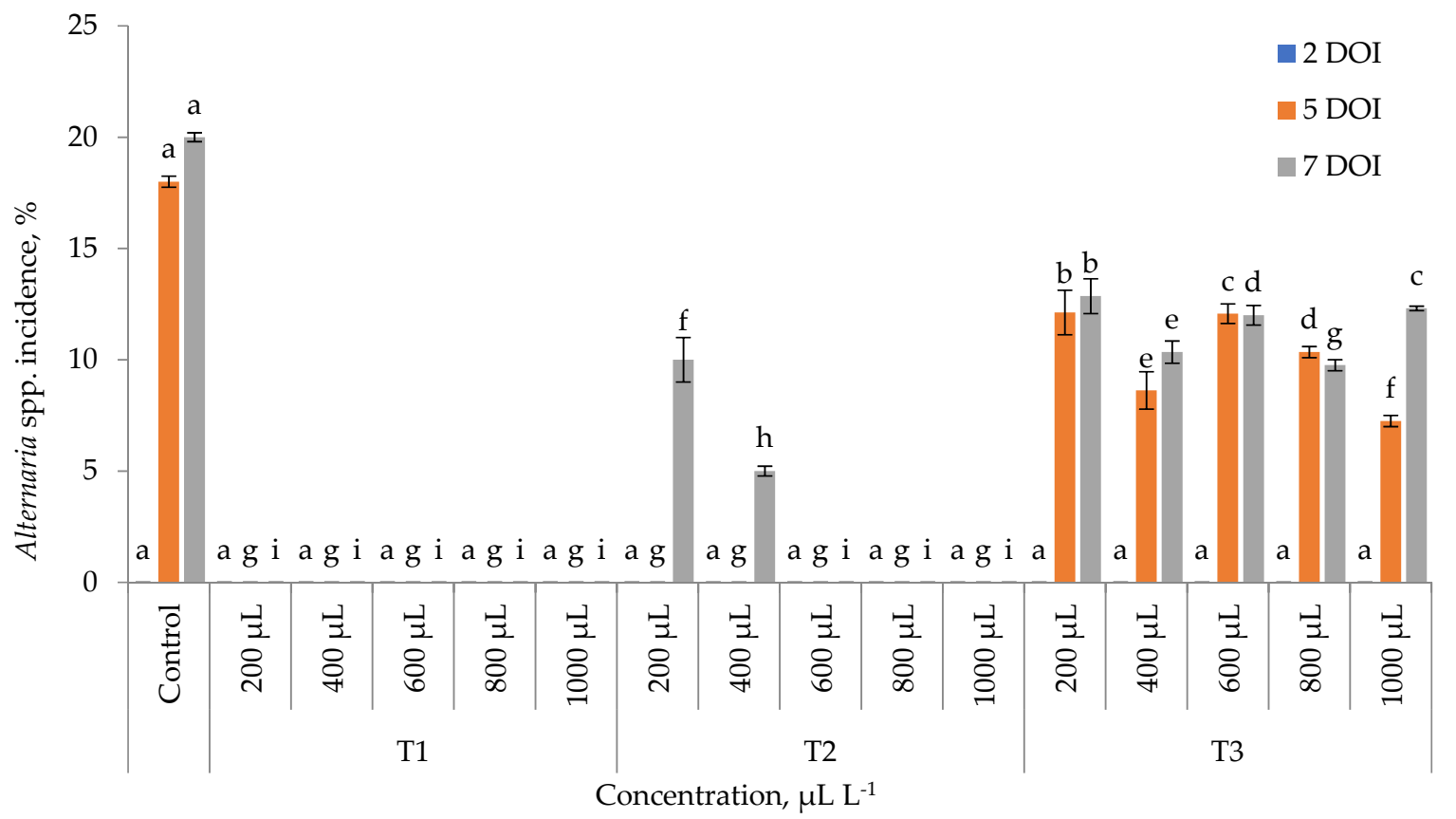

Figure 4. The incidence of Alternaria spp. on onion seeds under the influence of thyme (T1), hyssop (T2), and common juniper (T3) essential oils treatments after 2, 5, and 7 days of incubation (DOI); according to Duncan's multiple range test $(p<0.05)$, the same letters demonstrate no significant differences between treatments at 2,5, and 7 DOI.

T2 treatment also gave excellent inhibition of Alternaria fungi growth recorded only with 200 and $400 \mu \mathrm{L} \mathrm{L}^{-1}$ at 7 DOI.

However, the overall antifungal effect of T3 treatment at concentrations from 200 to $1000 \mu \mathrm{L} \mathrm{L}^{-1}$ was average compared to the control evaluating onion seeds at 2, 5, and 7 DOI. In addition, the augmentation of Alternaria spp. was observed in all treatments (control, T1, $\mathrm{T} 2$, and T3) at 2 DOI. Therefore, the 400 and $1000 \mu \mathrm{L} \mathrm{L}^{-1}$ of all T3 treatment concentrations had the best antifungal activity on Alternaria spp. incidence.

From all T1, T2, and T3 treatments applied on the carrot, tomato, and onion seeds, the $\mathrm{T} 1$ at all rates most significantly inhibited the growth of Alternaria spp., and concentrations from $400 \mu \mathrm{L} \mathrm{L}^{-1}$ of $\mathrm{T} 3$ also showed modest antimycotic results. It is important to remember that tomato and onion seeds had less internal contamination with pathogenic fungi than carrot seeds. 


\section{Discussion}

Innovative plant protection solutions are necessary due to the chemical fungicides' negative impact on ecology and seeds germination issues caused by infestation with Alternaria spp. [12,21,22]. Therefore, appropriate antifungal measures and their application strategy are crucial. The current study provides the latest findings regarding the antifungal effects of plant-based substances on the seed-borne fungi of the genus Alternaria isolated on tomato, carrot, and onion seeds.

Fungi incidence on vegetable seeds was significantly reduced by thyme (T1) treatment at all rates (200-1000 $\left.\mu \mathrm{L} \mathrm{L}^{-1}\right)$. There are numerous investigations about thyme essential oil antimicrobial impacts determined by the main chemotypes of thymol, $\gamma$-terpinene, p-cymene, $\beta$-caryophyllene, and carvacrol $[19,24,25,27,28,30-33]$. Some other experiments reported an effective control mechanism for Alternaria and other genera fungi on carrot and tomato seeds by this oil [30,31,33,45,46]. For example, Dorna and Szopińska [30] noticed that different applications of commercial oils involving thyme, possibly with $22-38 \%$ of thymol and 1-2\% carvacrol, reduced the fungal contamination of the carrot seeds (cultivar 'Flakkese 2'), including Alternaria alternata (Fr.) Keissl. micromycetes. Contrary, the incidence of Alternaria dauci (J.G. Kühn), J.W. Groves and Skolko, and Alternaria radicina Meier, Drechsler, and E.D. Eddy increased under this oil influence in the case of seed cultivar 'Amsterdam 3' [30]. The same good effects of the treatment were seen against Alternaria spp. when a 'Laguna' cultivar seed sample was stirred in $1 \%$ oil emulsion for four hours. Nevertheless, the authors emphasised that choosing the optimal concentration is critical due to inherent oil phytotoxicity, and they recommended pre-testing [31]. Our results with T1 (41.35\% of thymol) treatment support Riccioni and Orzali research [46], where a thyme essential oil ( $41 \%$ of thymol) concentration range of $0.05-1 \%$ considerably reduced the development of $A$. dauci in vitro.

Our results revealed that the effect on vegetable seeds was unequal when applying hyssop (T2) essential oil. It had the most negligible impact on carrot seeds, then better than average on tomato seeds, and the best fungi growth inhibition on onion seeds. It did not inhibit fungal development on carrot seeds and even promoted it compared to the control. Nonetheless, Fraternale et al. [47] have described various phytopathogenic fungi, like Rhizoctonia solani Ell. et Mart, Botrytis cinerea Pers., Fusarium graminearum Schwabe (ATCC 15624) as significantly sensitive to two hyssop essential oils. These oils were mainly characterised by pinocamphone (34\% and $18.5 \%), \beta$-pinene $(10.5 \%$ and $10.8 \%)$, and isopinocamphone (3.2\% and $29 \%$ ). Their experiment also revealed that concentrations of 1400 and $1600 \mu \mathrm{L} \mathrm{mL}^{-1}$ of both oils inhibited 13 different fungal plant pathogens by $100 \%$, Alternaria solani Ell. et Mart either. The seeds utilised in our experiments were characterised by higher contamination of Alternaria species. Thus, according to previously discussed results, the tested concentrations of T2 treatment were not high enough to achieve expected efficacy in our experiment. Still, the similarity between chemical compositions of T2 (cispinocamphone, $40.16 \%$; $\beta$-phellandrene, $12.51 \%$; $\beta$-pinene, $8.07 \%$ ) and earlier described hyssop oil [40] prompts a potentially optimistic effect of higher T2 concentrations. Moreover, many studies investigated hyssop antimicrobial properties on other microorganisms and substances of this herb exhibited undeniable prospects [48].

Our study found that common juniper T3 inhibited Alternaria spp. depending on seeds, and the concentration of $400 \mu \mathrm{L} \mathrm{L}^{-1}$ was most effective in all seed experiments. T3 active compounds were possibly $\alpha$-pinene (21.0-67.4\%) and myrcene (7.8-18.7\%). Other authors found that common juniper essential oil was effective against some soil- and seedborne pathogens. For example, in Zabka et al. [49] research, $1 \mu \mathrm{L} \mathrm{mL}^{-1}$ concentration of this oil moderately influenced pathogens, such as Fusarium verticillioides (Sacc.) Nirenberg, Fusarium oxysporum Schlechtendahl, Aspergillus fumigates Fresenius, Aspergillus flavus Link, Penicillium expansum Link, and Penicillium brevicompactum Dierckx; the effect on Alternaria species was not studied. Indeed, thyme oil was described as the most robust to reduce target fungi growth [49]. Additionally, good antimicrobial activity (A. flavus, A. niger, and 
Candida albicans (C.P. Robin) Berkhout) of methanolic extract of Juniperus communis L. was highlighted, emphasising the leading activity against $A$. niger and A. flavus [50].

To conclude, essential oils of hyssop and common juniper resulted in a moderate capability to control the seed-borne fungi on tested samples of vegetable seeds. Besides, results demonstrated that thyme essential oil had a significant reducing impact on the carrot, tomato, and onion fungi, affirming what is already published in the literature. Despite this, as in vitro effects do not always positively affect in vivo performances, further studies are required to prove the effectiveness in field conditions as seeds treatments and their possible phytotoxicity on the plant or seed material. Furthermore, thyme essential oil is a promising agent for vegetable seed-borne fungi Alternaria spp. management.

Author Contributions: Conceptualisation, S.C., N.R. and A.V.; methodology, S.C., N.R. and A.V.; software, S.C.; validation, N.R.; formal analysis, S.C.; investigation, S.C.; resources, N.R.; data curation, S.C.; writing-original draft preparation, S.C.; writing-review and editing, S.C., N.R. and A.V.; visualisation, S.C.; supervision, N.R. and A.V. All authors have read and agreed to the published version of the manuscript.

Funding: This research received no external funding.

Institutional Review Board Statement: Not applicable.

Conflicts of Interest: The authors declare no conflict of interest. The funders had no role in the design of the study; in the collection, analyses, or interpretation of data; in the writing of the manuscript, or in the decision to publish the results.

\section{References}

1. Tournas, V.H. Spoilage of vegetable crops by bacteria and fungi and related health hazards. Crit. Rev. Microbiol. 2005, 31, 33-44. [CrossRef] [PubMed]

2. Nowicki, M.; Nowakowska, M.; Niezgoda, A.; Kozik, E. Alternaria Black Spot of Crucifers: Symptoms, Importance of Disease, and Perspectives of Resistance Breeding. J. Fruit Ornam. Plant Res. 2012, 76, 5-19. [CrossRef]

3. Gaur, A.; Kumar, A.; Kiran, R.; Kumari, P. Importance of seed-borne diseases of agricultural crops: Economic losses and impact on society. In Seed-Borne Diseases of Agricultural Crops: Detection, Diagnosis E Management; Springer: Singapore, 2020; pp. 3-23. [CrossRef]

4. $\quad$ EPPO Standard. PP 2/1 (1) Guideline on good plant protection practice: Umbelliferous crops. Bull. OEPP/EPPO Bull. 1994, 24, 233-240.

5. Farrar, J.J.; Pryor, B.M.; Davis, R.M. Alternaria diseases of carrot. Plant Dis. 2004, 88, 776-784. [CrossRef] [PubMed]

6. Chaerani, R.; Voorrips, R.E. Tomato early blight (Alternaria solani): The pathogen, genetics, and breeding for resistance. J. Gen. Plant Pathol. 2006, 72, 335-347. [CrossRef]

7. Singh, V. Alternaria diseases of vegetable crops and its management control to reduce the low production. Int. J. Agric. Sci. 2015, 7, 834-840.

8. Mohsin, S.M.; Islam, M.R.; Ahmmed, A.N.F.; Nisha, H.A.C.; Hasanuzzaman, M. Cultural, morphological and pathogenic characterization of Alternaria porri causing purple blotch of onion. Not. Bot. Horti Agrobot. Cluj-Napoca 2016, 44, $222-227$. [CrossRef]

9. Solfrizzo, M.; Girolamo, A.D.; Vitti, C.; Tylkowska, K.; Grabarkiewicz-Szczęsna, J.; Szopińska, D.; Dorna, H. Toxigenic profile of Alternaria alternata and Alternaria radicina occurring on umbelliferous plants. Food Addit. Contam. 2005, 22, 302-308. [CrossRef]

10. Addrah, M.E.; Zhang, Y.; Zhang, J.; Liu, L.; Zhou, H.; Chen, W.; Zhao, J. Fungicide treatments to control seed-borne fungi of sunflower seeds. Pathogens 2020, 9, 29. [CrossRef]

11. Siciliano, I.; Gilardi, G.; Ortu, G.; Gisi, U.; Gullino, M.L.; Garibaldi, A. Identification and characterization of Alternaria species causing leaf spot on cabbage, cauliflower, wild and cultivated rocket by using molecular and morphological features and mycotoxin production. Eur. J. Plant Pathol. 2017, 149, 401-413. [CrossRef]

12. Zhang, X.; Wang, R.; Ning, H.; Li, W.; Bai, Y.; Li, Y. Evaluation and management of fungal-infected carrot seeds. Sci. Rep. 2020, 10, 10808. [CrossRef] [PubMed]

13. Davis, R.M. Carrot diseases and their management. In Diseases of Fruits and Vegetables; Naqvi, S.A.M.H., Ed.; Springer: Dordrecht, The Netherlands, 2004; Volume I, pp. 397-439.

14. González, M.; Caetano, P.; Sánchez, M.E. Testing systemic fungicides for control of Phytophthora oak root disease. For. Pathol. 2017, 47, e12343. [CrossRef]

15. Lamichhane, J.R.; You, M.P.; Laudinot, V.; Barbetti, M.J.; Aubertot, J.N. Revisiting sustainability of fungicide seed treatments for field crops. Plant Dis. 2020, 104, 610-623. [CrossRef] [PubMed] 
16. Singh, U.B.; Chaurasia, R.; Manzar, N.; Kashyap, A.S.; Malviya, D.; Singh, S.; Kannojia, P.; Sharma, P.K.; Imran, M.; Sharma, A.K. Chemical Management of Seed-Borne Diseases: Achievements and Future Challenges. In Seed-Borne Diseases of Agricultural Crops: Detection, Diagnosis E Management; Kumar, R., Gupta, A., Eds.; Springer: Singapore, 2020; pp. 665-682. [CrossRef]

17. Töfoli, J.G.; Domingues, R.J.; Tortolo, M.P.L. Effect of various fungicides in the control of Alternaria Leaf Blight in carrot crops. Biol. São Paulo 2019, 81, 1-30. [CrossRef]

18. Sharma, K.K.; Singh, U.S.; Sharma, P.; Kumar, A.; Sharma, L. Seed treatments for sustainable agriculture-A review. J. Appl. Nat. Sci. 2015, 7, 521-539. [CrossRef]

19. Mancini, V.; Romanazzi, G. Seed treatments to control seedborne fungal pathogens of vegetable crops. Pest Manag. Sci. 2014, 70, 860-868. [CrossRef]

20. The European Commission Regulation (EC) No. 1452/2003. Official Journal of the European Community. 2003. Available online: https:/ / eur-lex.europa.eu/LexUriServ/LexUriServ.do?uri=OJ:L:2003:206:0017:0021:EN:PDF (accessed on 9 March 2021).

21. Silva, V.; Mol, H.G.; Zomer, P.; Tienstra, M.; Ritsema, C.J.; Geissen, V. Pesticide residues in European agricultural soils-A hidden reality unfolded. Sci. Total Env. 2019, 653, 1532-1545. [CrossRef]

22. Cozma, P.; Apostol, L.C.; Hlihor, R.M.; Simion, I.M.; Gavrilescu, M. Overview of human health hazards posed by pesticides in plant products. In Proceedings of the 2017 E-Health and Bioengineering Conference (EHB), Sinaia, Romania, 22-24 June 2017; IEEE: Piscataway, NJ, USA, 2017; Volume 17066084, pp. 293-296. [CrossRef]

23. Ložienè, K.; Venskutonis, P.R. Juniper (Juniperus communis L.) oils. In Essential Oils in Food Preservation, Flavor and Safety; Academic Press: Cambridge, MA, USA, 2016; pp. 495-500. [CrossRef]

24. Hanif, M.A.; Nisar, S.; Khan, G.S.; Mushtaq, Z.; Zubair, M. Essential oils. In Essential Oil Research; Springer: Cham, Switzerland, 2019; pp. 3-17. [CrossRef]

25. Valdivieso-Ugarte, M.; Gomez-Llorente, C.; Plaza-Díaz, J.; Gil, Á. Antimicrobial, antioxidant, and immunomodulatory properties of essential oils: A systematic review. Nutrients 2019, 11, 2786. [CrossRef]

26. Moulodi, F.; Khezerlou, A.; Zolfaghari, H.; Mohamadzadeh, A.; Alimoradi, F. Chemical Composition and Antioxidant and Antimicrobial Properties of the Essential Oil of Hyssopus officinalis L. J. Kermanshah Univ. Med. Sci. 2018, 22, e85256. [CrossRef]

27. Dauqan, E.M.; Abdullah, A. Medicinal and functional values of thyme (Thymus vulgaris L.) herb. J. Appl. Biol. Biotechnol. 2017, 5, 17-22. [CrossRef]

28. Karaca, G.; Bilginturan, M.; Olgunsoy, P. Effects of some plant essential oils against fungi on wheat seeds. Indian J. Pharm. Educ. Res 2017, 51, S385-S388. [CrossRef]

29. Muthukumar, A.; Sangeetha, G.; Naveenkumar, R. Antimicrobial activity of essential oils against seed borne fungi of rice (Oryza sativa L.). J. Environ. Biol. 2016, 37, 1429-1436.

30. Dorna, H.; Qi, Y.; Szopińska, D. The effect of acetic acid, grapefruit extract and selected essential oils on germination, vigour and health of carrot (Daucus carota L.) seeds. Acta Sci. Pol. Hortorum Cultus 2018, 17, 27-38. [CrossRef]

31. Koch, E.; Schmitt, A.; Stephan, D.; Kromphardt, C.; Jahn, M.; Krauthausen, H.J.; Forsberg, G.; Werner, S.; Amein, T.; Wright, S.A.I.; et al. Evaluation of non-chemical seed treatment methods for the control of Alternaria dauci and A. radicina on carrot seeds. Eur. J. Plant Pathol. 2010, 127, 99-112. [CrossRef]

32. Morkeliūnè, A.; Rasiukevičiūtè, N.; Šernaitè, L.; Valiuškaitè, A. The Use of Essential Oils from Thyme, Sage and Peppermint against Colletotrichum acutatum. Plants 2021, 10, 114. [CrossRef]

33. Soković, M.D.; Vukojević, J.; Marin, P.D.; Brkić, D.D.; Vajs, V.; van Griensven, L.J.L.D. Chemical composition of essential oils of Thymus and Mentha species and their antifungal activities. Molecules 2009, 14, 238-249. [CrossRef]

34. Graj, W.; Lisiecki, P.; Szulc, A.; Chrzanowski, Ł.; Wojtera-Kwiczor, J. Bioaugmentation with petroleum-degrading consortia has a selective growth-promoting impact on crop plants germinated in diesel oil-contaminated soil. Water Air Soil Pollut. 2013, 224, 1676. [CrossRef]

35. Mathur, S.B.; Kongsdal, O. Common Laboratory Seed Health Testing Methods for Detecting Fungi, 1st ed.; International Seed Testing Association: Bassersdorf, Switzerland, 2003; 425p, ISBN 3906549356.

36. Acumedia. A Subsidiary of NEOGEN Corporation. Neogen Food Safety. Potato Dextrose Agar (7149)-Protocol. PI7149 Rev 4. 2011. Available online: http://biotrading.com/assets/productinformatie/acumedia/tds/7149.pdf (accessed on 10 March 2021).

37. Thobunluepop, P. The inhibitory effect of the various seed coating substances against rice seed borne fungi and their shelf-life during storage. Pak. J. Biol. Sci. 2009, 12, 1102. [CrossRef]

38. Mancini, V.; Murolo, S.; Romanazzi, G. Diagnostic methods for detecting fungal pathogens on vegetable seeds. Plant Pathol. 2016 65, 691-703. [CrossRef]

39. Mamgain, A.; Roychowdhury, R.; Tah, J. Alternaria pathogenicity and its strategic controls. Res. J. Biol. $2013,1,1-9$.

40. Stankevičienè, A.; Lugauskas, A. Mikromicetu ivvairovė augalų rizosferoje skirtingose oranžerijos sekcijose. Vytauto Didžiojo Univ. Bot. Sodo Raštai = Scr. Horti Bot. Univ. 2008, 12, 84-93.

41. AOAC. Volatile oil in spices. In Official Methods of Analysis, 15th ed.; Helrich, K., Ed.; Association of Official Analytical Chemists: Washington, DC, USA, 1990; Volume 1

42. Šernaitè, L.; Rasiukevičiūtè, N.; Valiuškaitè, A. The extracts of cinnamon and clove as potential biofungicides against strawberry grey mould. Plants 2020, 9, 613. [CrossRef] [PubMed]

43. Judžentienè, A. Juniperus communis L.: A review of volatile organic compounds of wild and cultivated common juniper in Lithuania. Chemija 2019, 30, 184-193. [CrossRef] 
44. Morkeliūnè, A.; Rasiukevičiūtè, N.; Valiuškaitè, A. Pathogenicity of Colletotrichum acutatum to different strawberry cultivars and anthracnose control with essential oils. Zemdirb. Agric. 2021, 10, 173-180. [CrossRef]

45. Alexa, E.; Sumalan, R.M.; Danciu, C.; Obistioiu, D.; Negrea, M.; Poiana, M.A.; Dehelean, C. Synergistic antifungal, allelopatic and anti-proliferative potential of Salvia officinalis L., and Thymus vulgaris L. essential oils. Molecules 2018, 23, 185. [CrossRef]

46. Riccioni, L.; Orzali, L. Activity of tea tree (Melaleuca alternifolia, Cheel) and thyme (Thymus vulgaris, Linnaeus.) essential oils against some pathogenic seed borne fungi. J. Essent. Oil Res. 2011, 23, 43-47. [CrossRef]

47. Fraternale, D.; Ricci, D.; Epifano, F.; Curini, M. Composition and antifungal activity of two essential oils of hyssop (Hyssopus officinalis L.). J. Essent. Oil Res. 2004, 16, 617-622. [CrossRef]

48. Judžentienè, A. Hyssop (Hyssopus officinalis L.) Oils. In Essential Oils in Food Preservation, Flavor and Safety; Academic Press: Cambridge, MA, USA, 2016; pp. 471-479. [CrossRef]

49. Zabka, M.; Pavela, R.; Slezakova, L. Antifungal effect of Pimenta dioica essential oil against dangerous pathogenic and toxinogenic fungi. Ind. Crops Prod. 2009, 30, 250-253. [CrossRef]

50. Menghani, E.; Sharma, S.K. Antimicrobial activity of Juniperus communis and Solanum xanthocarpum. Int. J. Pharm. Sci. Res. 2012, 3, 2815. [CrossRef] 